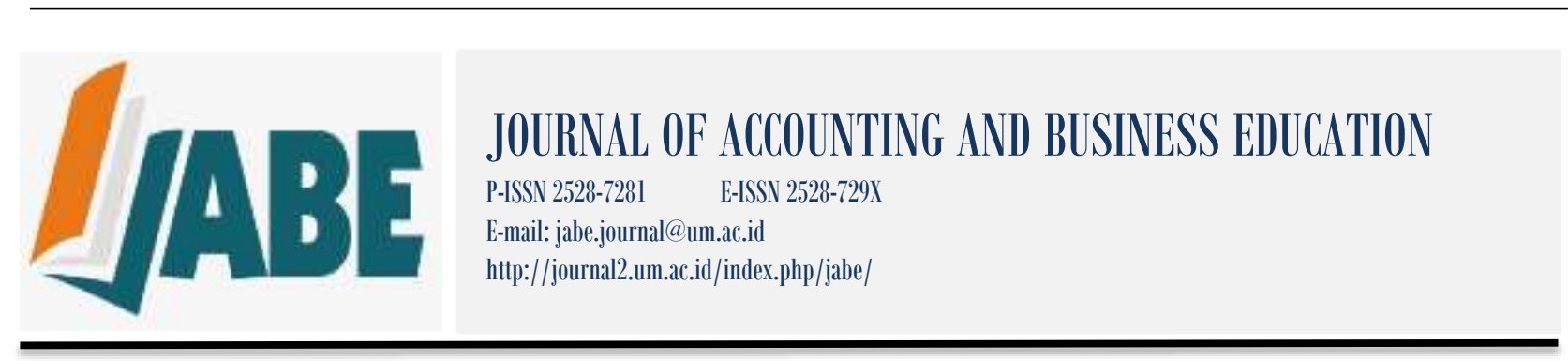

\title{
Deliberative CSR: Alternative CSR Concept based on Liberation Theology Perspective
}

\author{
Astri Dyastiarini ${ }^{1}$ \\ Gugus Irianto $^{2}$ \\ Roekhudin $^{3}$ \\ ${ }^{1,2,3}$ Accounting Department, Faculty of Economic and Business, Universitas Brawijaya, Indonesia \\ email: astridyast@gmail.com
}

\begin{abstract}
Theories underlying the CSR concept only takes side of secular world because it is based on materialistic world view which directs CSR practice at pragmatic goals. Therefore, CSR needs conceptual development which is able to balance material and spiritual worlds. The objective of this research is to develop CSR concept through elaboration of divine values based on liberation theology. Liberation theology presents three main principles, namely, 1) Equitable distribution of wealth, 2) Managing earth as mandate of creation, and 3) Fulfilling basic human rights. The principle is taken as the basis to arrange the deliberative CSR concept that is able to promote a civil society. This research employed a qualitative approach with critical paradigm to interpret the phenomena and reconstruct CSR concept. The results of this research are: 1) The concept of tazkiah or soul purification in economic case, that is purifying human by spending their wealth in the way of Allah; 2) The concept of justice, as the basis to settle poverty issue; 3 ) Natural balance as the basis of utilizing natural resources; 4) Social welfare, which is the Prophet's revolutionary mission through liberating human from ignorance, oppression, slavery, and poverty. The implication is that deliberative CSR liberates CSR from materialism's capitalistic worldview. Deliberative CSR makes entity perform CSR beyond the obligation; which is as human necessity to actualize their duties as God's representative on earth as the consequence of devotion to Allah SWT.
\end{abstract}

Citation: Dyastiarini, A., Irianto, G., Roekhudin, R.. (2021). Deliberative CSR: Alternative CSR Concept based on Liberation Theology Perspective. Journal of Accounting and Business Education, 6 (1),49-60

\section{INTRODUCTION}

Corporate Social Responsibility (CSR) has become one of the most orthodox concepts generally accepted in the business world (Carrol and Sabana, 2010). It is called orthodox since CSR implementation is only to comply with legal requirements. In Indonesia, CSR is mandatory for each limited liability company (Lako, 2011) as set forth in Law (UU) No. 40 of 2007 . Initially, CSR is vaguely framed in moral and macro-social term (Lee, 2008) and not desired by business players since shareholders cannot see how CSR is able to serve their interest and influence company's performance and management.

In the last decade, CSR is debated with regard to its influence on company's financial performance. Many academics and theoreticians explain why company performs social responsibility. The stakeholder 
theory (Freeman \& David, 1983) emphasizes that a company must manage the interest of various stakeholders as a strategy to maintain a good relationship for the company' survival. The legitimacy theory (Deegan, 2002) shows that CSR is performed as company's strategy to legitimize its existence in the social environment for it to utilize any resources it needs. The social contract theory states that company has a contract with the society that will endanger its survival if the society considers it violating the contract.

All of the theories above form CSR praxis which only takes side of secular life, since it is based on materialistic worldview. Materialistic CSR praxis will be directed to pragmatic goals, such as branding, appreciation, or legitimacy. Consequently, the current CSR concept does not indicate that there is a relationship between world life and the afterlife (Triyuwono, 2016). Although able to use them." Ford's business idea as a service to society was not only mocked by the shareholders, but also by the court that granted Dodge Brothers' request to acquire the maximum dividend. Dodge Brothers did not see any rational relationship between CSR and profit and most of the shareholders investing in the company did not make any difference in the society but gained substantial profit from investment.

CSR is evidently able to improve corporate performance, unfortunately, however, CSR is not yet able to complete is mission as company's commitment to social and environmental issues. According to Sanders (2012), the failure of whole CSR is based on the fact that this field of study deeply is instilled in neoliberal ideology.

Neoliberalism ensures competition between the bourgeoisie to expand the market, aiming at gaining profit and collect wealth (Irianto, 2006). The consequence is moral dislocation and unhealthy conflict among social hierarchy, including exploitation of natural and human resources, even manipulation of the need for goods/services are in demand, desire commodification, class domination, and economic inequality.

On the other hand, tauhid worldview does not dichotomize material world and the afterlife. Tauhid, which is commonly defined as Oneness of God, also means unity of humans (Engineer, 1999), and its promotion in secular tradition is an impossibility. Each human act, in tauhid world view, is performed as an embodiment of obedience of God Almighty. Consequently, humans do not only pursue material dimension, but also improve spiritual dimension. Therefore, elaboration of CSR concept with religious principles will direct CSR concept to divine consciousness (Gallhofer \& Haslam, 2004). Therefore, religion is expected to influence individual preference regarding CSR aspect.

Some beliefs give significant direction to ethical business practice that is able to promote a civil society as the ideal of all religions. Civil society is a social system growing based on faith which upholds the values of virtue. The society built by Prophet Muhammad p.u.b.h. is a real embodiment of civil society. Civil society is one main issue discussed in al-Qur'an, indicating the importance of social piety. Oppression removal is a requirement for promoting civil society (Engineer, 1999), since justice is the main characteristic of civil society .

Justice is an Islamic spirit as a distorted revolutionary ideology in line with the growth-development of power conflict after the Prophet's death. Islam loses its vitality as a revolutionary religion which brings justice mission. Liberation theology comes to release religion from its establishment. Liberation theology is different from traditional (classical) approach which is abstract and ahistorical, and emphasizes on individual piety which ignores social piety. Liberation theology suggests an integration of spiritual vision of God's law, which is based on the scripture, to provide alternative philosophical framework of human relationship with the nature and other creatures (Engineer, 1999).

Majority of researches on CSR are encouraged by debates on measuring instrument, disclosure standard, and impact to company. For example, CSR's impact on corporate value (Porter \& Kramer, 2002); (Rakotomavo, 2012), financial performance (Stuebs \& Sun, 2015); (Karaye et al., 2014); (Waworuntu et al., 2014), competitive advantage (Lee et al., 2013), and improvement of corporate image and reputation (Boubakary \& Moskolaï, 2016); (Smirnova, 2012). Only 13.9\% study CSR concept itself (Croker \& Barnes, 2017). Therefore, this research tries to study CSR concept critically.

The objective of this research is to develop CSR concept through elaboration of divine values based on liberation theology, thus it gives ethical guidance directing to the effort to promote civil society. This 
research contributes to improving and developing CSR concept by balancing material dimension and spiritual dimension; thus piety to Creator is the reason of CSR implementation.

\section{LITERATURE REVIEW AND HYPOTHESES}

\section{Religion: opium of establishment or revolutionary ideology?}

Marx states that religion is opium and Nietzsche assumes God has died. Religion, according to Marx, only makes people only sigh with oppression and is even used to perpetuate establishment. "Willingness" and "patience" are understood as a form of acceptance of fate that the Creator has determined, while injustice does not descend from the heaven, but is human construct instead. Al-Qur'an firmly denies superiority and dominance which create oppression. Religion is created not to weaken humans, but as a life guidance for each individual to return to Him as the goal of life perfection. Islam calls itself sirath al-mustaqim (Muthahhari, 1993).

\section{Liberation theology: religious relevance in social context}

Liberation theology comes to relieve religion from its establishment. After the Prophet's death, Islam became a religion which was laden with feudalistic praxis and supported establishment (Engineer, 1999:4-8). Liberation theology is characteristically praxis and is not merely theoretical which is full of obscurity and abstract matters. According to Engineer (1999), liberation theology starts with seeing human condition in the world and in the afterlife, anti-establishment, and serves to defend those oppressed and gives ideology to fight oppression.

Social justice is the obligation of each individual who believes in the existence of God. When a believer tries to enslave others, then he wants to be God, while there is no God but Allah. Believing in God automatically bears the consequence of promoting justice, since justice is rooted in Tauhid. Islam commands us to be just since it is close to taqwa (righteousness) and those who are taqwa are close to God.

Injustice may be destroyed through an organized religion. An organized religion plays an important role in building and spreading ethical guidelines which conform to religious doctrines and proposes practical guidelines on running a business (Brammer et al., 2007). Religion becomes believers' guidelines on undergoing their life, including in economic field.

\section{CSR Liberation: elaboration of divine values}

Viewing CSR from the framework of liberation theology is an effort to promote holistic CSR praxis. CSR as a strategy is always directly associated with corporation's core of business (Porter \& Kramer, 2002). Consequently, any forms of CSR praxis must be directed to creating value for company. Accumulation of profit in the capitalism is intended to collect personal wealth, while Islam does not justify it . CSR wrapped in capitalism will only take dominant class's side. Therefore, it is important to liberate CSR from the body of capitalism for CSR praxis to promote collective humanity or civil society.

\section{Capitalism vs Liberation Theology}

Capitalism prioritizes competition with the logics "the strong wins" leading to damaged solidarity. Differently from Islam, capitalism upholds competition to collect wealth in order to be ruling class. Ruling class will consider themselves superior, giving them the right to dominate, oppress, and alienate inferior groups. Meanwhile, Islam and other heavenly religions prioritize brotherhood and humanity with justice spirit.

CSR in capitalism's logics is only used as a new strategy to win competition, which is adapted to society's hope for corporation's practice which considers sustainability aspect. However, when reviewed more thoroughly, CSR is an effort to improve corporate value through positive branding as confirmed with an award. This is as contained in Presidential Regulation No. 47 of 2012 that company that has played a role in and implemented social and environmental responsibilities may be given with award.

Meanwhile, in religious teaching, helping or giving assistance is performed by the right hand without the left hand's awareness. This means that it is performed only for God's pleasure. In addition, 
collecting wealth in Islamic teaching is prohibited since it will deepen poverty, while poverty is the worst human nature. This poverty challenge must be responded by building a social structure which is free from exploitation, alienation, and concentration of wealth on a handful of people (Engineer, 1999).

\section{Civil society as the goal of CSR practice}

Since the end of 1980s, civil society got more attention and interest with regard to the fall of many socialist regimes previously in the East Bloc such as the authoritarian regimes in Latin America, Asia, and Southeast Asia (Beittinger-Lee, 2013). Civil society gives dominant role to individual as independent human . CSR is corporation's program as the embodiment of their responsibility for environmental and socio-economic issues caused by their business operation (Stohl \& Stohl, 2010). Collective humanity becomes the characteristics of civil society, which is upholding humanity.

\section{METHODS}

This research employed qualitative approach. Qualitative approach is deemed appropriate to achieve the research's objective, which is CSR concept development. Qualitative tends to prioritize inductive logical thinking, where classification of problems is obtained from the meeting between research and informant in the field or from the data found (Creswell, 2013).

This research employed critical paradigm. Critical paradigm emphasizes the importance of deconstruction and reconstruction (Djamhuri, 2011). This is in line with the research's objective, which is reconstruction of CSR concept. Therefore, critical paradigm is the most appropriate worldview to observe, interpret and define related phenomena.

The data were analyzed using liberation theology. In the book "Islam and Liberation Theology", Engineer (1999) concentrates his attention on social injustice and inequality developing in the society. Engineer aims at releasing religion from limitations constructed by rulers, where religion is taken only ritual worship for individual piety while discrediting social piety. In order to achieve the aim, Engineer dialecticizes social phenomena with verses of al-Qur'an.

The research site chosen was PT. Semen Tonasa Tbk (PTST). PTST was a go public company operating in mining sector, in which mining industry was a business activity with the biggest contribution of environmental damage. PTST won TOP CSR 2017 for SDG category Environment Impact Reduction and its Managing Director was chosen as the TOP Leader on CSR Commitment. One year before this award, PTST was protested by surrounding society since it did not implement CSR for four years. Based on the phenomena, the researcher was interested to study and investigate PTST's CSR practice.

The types of data employed in this research were as follows:

1. Secondary data

The secondary data were in the form of official document divided into internal and external documents. Internal document includes annual report, financial reporting, sustainability reporting, and other related documents from internal organization. External document was information from external source of organization, such as through certain media or institution.

2. Primary data

The primary data were data directly obtained from the source without any intermediary. The primary data the result of interview or observation on object studied.

The techniques employed to collect the data were as follows:

\section{Documentation}

Document has long been used in research as data source, used to test, interpret, and even forecast (Moleong, 2013). The data needed in this research were annual report, sustainability report, and other data related to PTST's CSR. The researcher also chose the last three years, which was period of report 2016 which made PT. Semen Tonasa Tbk. win CSR Award, and years 2015 and 2014 when the society demanded PTST's social responsibility.

2. Observation

The observation technique required researcher to be involved in the daily activities of people/group observed (Sugiyono, 2009), used as the research's source of data. Through observation, the data obtained 
would be complete, in-depth and the research might find to what extent the meaning of each observable behavior.

3. Interview

Interview was the instrument to prove information or certification obtained previously (Moleong, 2013). The interview was conducted in an unstructured manner aiming at finding non-standard information and reemphasizing interpretation. The informants taken as the primary source of data were as follows:

Table 1. Research Informants

\begin{tabular}{ccc}
\hline No. & Name & Status \\
\hline 1. & IHM & Biro CSR/PKBL \\
2. & AKF & Partnership Program Section \\
3. & PE & Environmental Development Section \\
4. & AN & Biring Ere Village \\
5. & MR & BPD of Biring Ere \\
6. & IS & Development Partner \\
7 & IB & Development Partner \\
\hline
\end{tabular}

There were some initial steps conducted by the research before arranging the research design. The research's flowchart may be illustration in the drawing below.

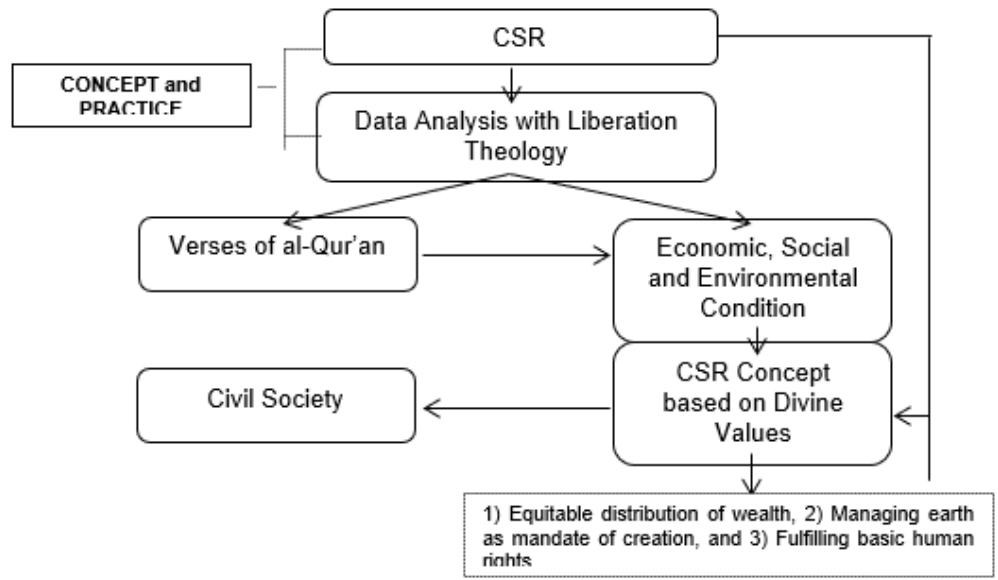

Figure 1. Research Flow Design

\section{RESULTS AND DISCUSSION}

Islam is a revolutionary ideology. Its arrival serves as the marker of changes, not only in belief in the Creator, but also in social and economic life. Islam that does not care about socio-economic issues changes Islam's image from revolutionary to non-contextual. Therefore, liberation theology comes to return Islam's commitment to creation of socio-economic justice.

According to Engineer (1999), liberation theology has the characteristics: First, views human condition in the world and the afterlife; Second, it does not desire status quo; Third, it struggles those oppressed; Fourth, it does not only acknowledge one metaphysical concept of fate, but also acknowledges individual freedom concept.

\section{Liberation Theology's Perspective in Company's Social Responsibility}

Responsibility is an embodiment of human's awareness of their obligations on their acts, either or not deliberately. Humans assume Allah's mandate, while the heaven, earth and mounts do not will to assume it. As the essence of its creation as khalifah, humans are assigned to be leader on earth, thus they are obliged to fulfil the mandate. The amanah character is not only directed to Allah as the highest authority in life, but also to humans. Therefore, humans should determine law fairly. 
Social justice is a strong foundation for ukhuwah islamiyah, which is with even socio-economic distribution . Khurshid et al. (2014) state that all society members have the right to be given with basic needs, regardless of race, religion, language, skin, sex, age, health, and status. Rice (1999) states that Islam provides complete life codes, which direct each phase of human life; spirituality, economic justice, and social justice, including business affairs.

The exploitative capitalism system causes unjust socio-economic structure, that there is no political justice, social justice, and economic justice. The form of exploitation in capitalist system is not compatible with Islam's justice doctrine. That is why modern capitalist society cannot cooperate with Islam's worldview (Engineer, 1999). There is no absolute ownership in Islam, which is quite different from capitalism, which glorifies personal ownership.

Al-Qur'an and hadith clearly state that in fighting poverty, ownership is not absolute but must be shared justly to those in need (Engineer, 1999). Unfortunately, distributive justice is narrowed down to shadaqoh. It is correct that Islam suggests charity to eradicate poverty, but shadaqoh is not the only best way. Engineer (1999) explains the importance for social institution to manage wealth to prevent curses and reproaches. Human's ownership of wealth is directed to the shared welfare (Engineer, 1999).

CSR attempts to improve corporate image by present it as humane and socially responsible business player, but may also be deemed as a mask to pursue limitless benefit and power (Khurshid, et al., 2013). The stigma cannot be separated from capitalistic business paradigm. According to (Dusuki, 2008), CSR in the West pays more attention to materialistic instead of ethic matter, since it is based on secular Western theories. In comparison to Western theories, Islam assumes a relatively holistic approach to CSR concept.

Islamic basic values, such as aqidah (faith and belief), ibadah (act of filial piety to Allah), and akhlaq (morality and ethics), will not change even if the time changes. These Islamic basic values are promoted in syari'ah which is the Islamic basic worldview. Muslims are bound by this law as the consequence of tauhid (belief/faith in Allah). CSR concept in Islam covers a wider implication including the dimension of taqwa (believing in Allah) which considers business as a group of individuals playing a role in and responsible for services and representative (khalifah) in any situation.

Islam as the liberation theology with the spirit of anti-status quo requires three basic concepts (Engineer, 1999) to promote a just society order, namely: 1) equitable distribution of wealth; 2) managing earth as mandate of creation; and 3) fulfilling basic human rights. Just society order is the characteristics of civil society. The firs principle is taken as the basis in the economic aspect of CSR concept, namely: 1) The Concept of Tazkia, and 2) The Concept of Justice. The second principle as taken as the basis in environmental aspect, namely: The Balance of Nature. The third principle is taken as the basis in social aspect, namely: Social Welfare. The concept of social responsibility in Indonesia is set forth in No. 40 of 2007 and elaborated in the technical regulation as in figure 2.

CSR concept in Islam covers a wider implication including the dimension of taqwa (believing in Allah), thus business entity must also account for all of their acts to Allah as the owner of earth along with anything therein. CSR concept in Islam will bring the spirit of liberation which is anti-status quo, thus CSR is understood as jihad to destroy oppressing socio-economic structure. Without jihad, one's faith is not perfect. Therefore, CSR concept elaborated from Islamic principles attempts to promote a society order which raises human level essentially and promote civil society.

CSR concept which is grounded on materialistic worldview will direct CSR practice which only takes side of life. Secular CSR does not indicate relationship between worldly life and the afterlife. This contradicts Islamic worldview. Islam reminds humans not to be occupied by worldly affairs and ignore afterlife affairs. Meanwhile, the CSR concept in the perspective of liberation theology may be viewed in the figure 3 . 


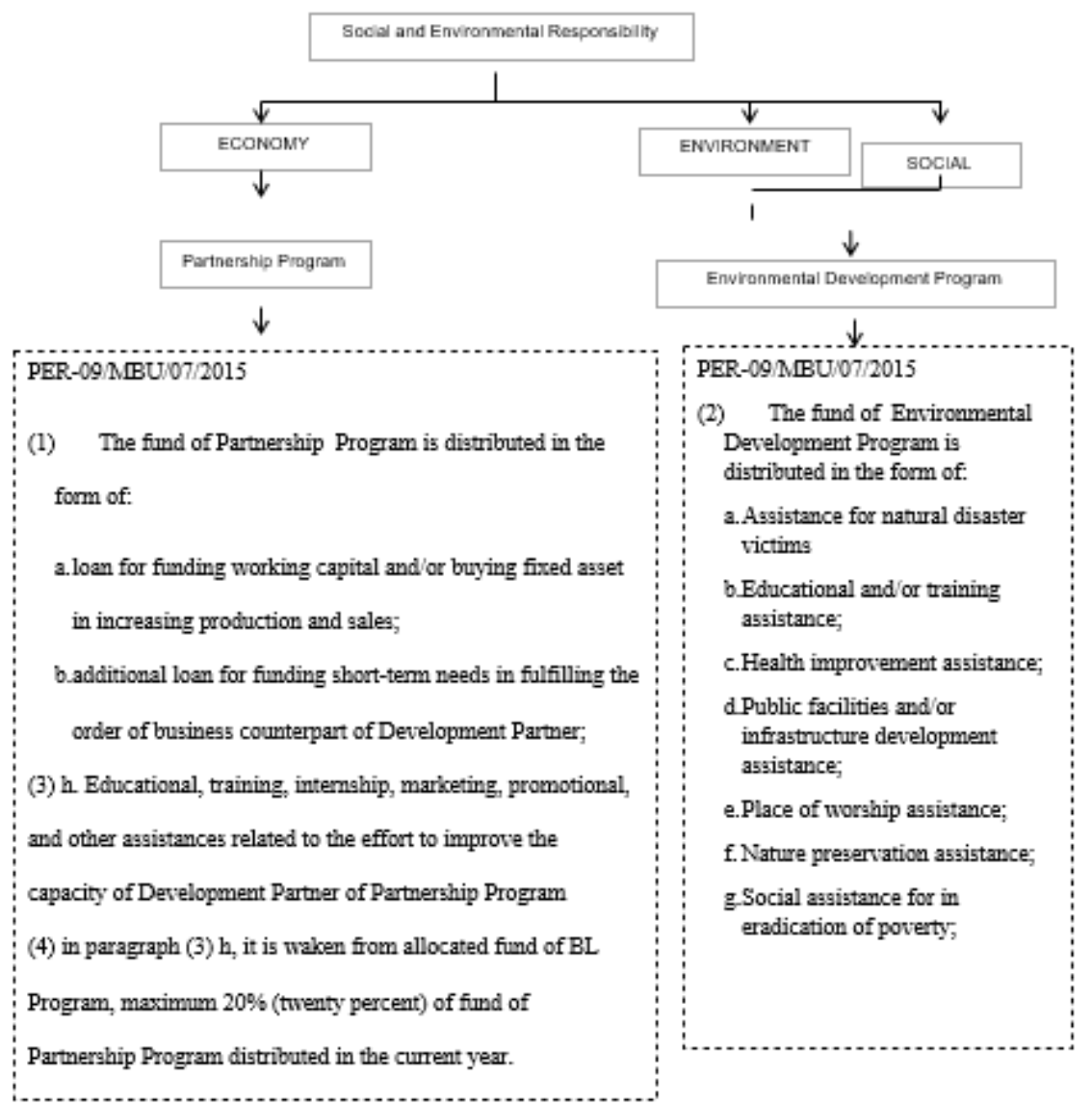

Figure 2. The concept of social responsibility in Indonesia

\section{CSR Concept in Liberation Theology}

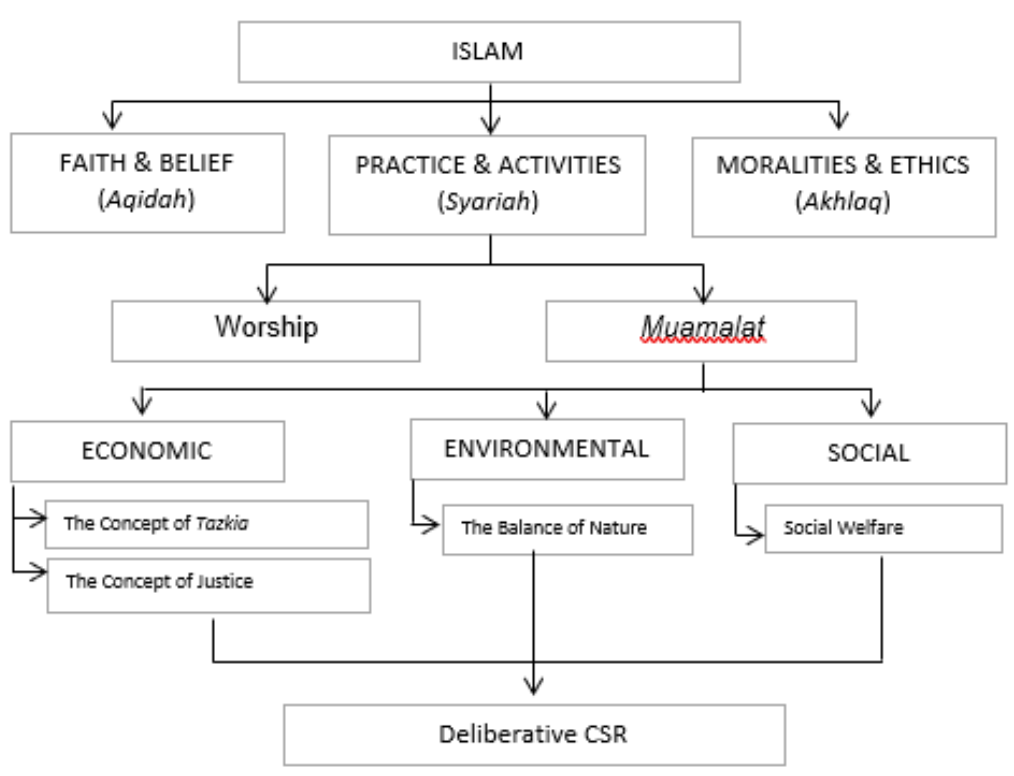

Figure 3. CSR Concept in Liberation Theology's Perspective 


\section{The Concept of Tazkia}

Islamic ethical system is different from secular ethical system. Secular ethical system is formed from man-made theories (Hassan, 2016), thus it only considers worldly life. Islamic ethical system is sourced from al-Qur'an and hadith, emphasizing relationship between human and The Creator. Therefore, the concept of development in Islam also pays attention to spirituality aspect as revealed by (Gambling \& Karim, 1986).

"The concept of Tazkia, or growth and purification, is the idea of active contribution in the material world. This concept entails that Muslims are required to participate in worldly activities with the provision that any material development and growth should also guarantee social justice and spiritual improvement. One of the key features of the Islamic ethical system is that it provides no separation between an individual's public and private lives (in the eyes of God)."

Tazkia is active contributive idea in material world requiring Muslims to actively take part in worldly activities provided that each material development and growth must ensure social justice and spiritual improvement. The meaning of tazkia by term is self-purification from any disease, realizing various maqam on it and making asma and shifat as the character (Al-Ghazali, 1996). This soul purification will cleanse human from any manners which do not conform to their nature.

According to (Triyuwono, 2016), management which only focuses on achieving profit will stimulate over-egoistic behavior and keep organization away from ethical and human values. Human's distance from ethical values will erode their human nature. Therefore, humans are commanded to cleanse themselves and return to their nature as khalifah.

"But the righteous will be spared from it-who donate "some of" their wealth only to purify themselves, not in return for someone's favors, but seeking the pleasure of their Lord, the Most High." (QS. al-Layl [92]:17-20).

Allah promises those donating their wealth only for seeking His pleasure will be kept away from the hell. The concept of tazkia in this case is to cleanse human soul and each of their acts by balancing worldly and heavenly affairs, that is to spend their wealth in the way of Allah. Islam does not separate individual's personality from personal life.

\section{The Concept of Justice: Taqassata}

Justice is society's highest measure (Engineer, 1999). Justice in Islam is rooted from tauhid; thus the real meaning of taqwa is not only to perform ritual worship. Each faithful individual is commanded to act justly because God Almighty loves those who act justly. Poverty must be responded by building social structure which is free from exploitation, oppression, and collection of wealth by a handful of people or group. Allah swt says:

"Give good news of a painful torment to those who hoard gold and silver and do not spend it in Allah's cause. The Day 'will come' when their treasure will be heated up in the Fire of Hell, and their foreheads, sides, and backs branded with it. "It will be said to them, "This is the treasure you hoarded for yourselves. Now taste what you hoarded!"” (QS. at-Tawbah [9]:34-35).

The verse above depicts God's punishment for those who hoard wealth. This is different from capitalist concept of adoring wealth. Allah makes laws as the consequence of how humans are in multistage in sustenance; such as livelihood, zakat, and kafarat. On the laws, Allah reminds humans of his dearly sanction.

"Whenever We intend to destroy a society, We command its elite 'to obey Allah' but they act rebelliously in it. So the decree 'of punishment' is justified, and We destroy it utterly." (QS. al-Isra' [17]:16).

It is clear that rich men (that is those with over-sustenance) do not care the weak and those oppressed, thus all social structure will be chaotic and destroyed by revolution (Engineer, 1999:54). There are many evidences The Creator has given of His laws; such as the story of Prophet Nuh, the story of Prophet Luth, the story of Prophet Sulaiman, Tsunami in Aceh, and Earthquake in Padang. 
The Balance of Nature The Cartesian-Newtonian Paradigm considers the nature inferior and the object of be controlled by human. Although human is created as venerated being, Islam does not make human dominate other creations. Tauhid worldview positions human as khalifah, carrying the mandate that the heaven, earth and mounts are unable to assume. Created as khalifah, human is required to keep the earth from destruction because of previous humans' greed. Allah says:

"Remember" when your Lord said to the angels, "I am going to place a successive "human" authority on earth." They asked 'Allah", "Will You place in it someone who will spread corruption there and shed blood while we glorify Your praises and proclaim Your holiness?" Allah responded, "I know what you do not know."”' (QS. al-Baqarah [2]:30)

Earth is not created without any wisdom, but with correct goals. Therefore, God prohibits human from destroying the earth, as Allah says below:

"Do not spread corruption in the land after it has been set in order. And call upon Him with hope and fear. Indeed, Allah's mercy is always close to the good-doers." (QS. al-A'raf [7]:56).

Destruction on earth means spreading disobedience, hostility, and injustice on earth. Islam considers business to have socially useful function. Business, as human association, is required to get involved in sustainable development activity (Hassan, 2016), thus it can reduce environmental impact and help provide, protect, and preserve the environment to inhabit.

\section{Social Welfare}

Social welfare is one of the main subjects of Islamic teaching. This can be observed from the Prophet's life story. He was born in Mecca in an illiterate society. The time before Islam came was called the era of ignorance. The society's social view at that time was narrow and they rejected any view other than their ancestral tradition.

At 40 years old, the Prophet liberated Mecca and all mankind (Engineer, 1999). The Prophet liberated them from suffering, superstition, oppression, slavery, and injustice. He also liberated those oppressed, the poor, and those ignorant (Engineer, 1999). All of it was not only performed through being teacher and philosopher, but also activists who were involved in the field in the society's economic activities.

The revolution performed by the Prophet is Allah's command. Allah says the importance of scientific knowledge, which is likened to be nur (light). Allah also removes superstition and tribal perspective, and gives equal right to women. All of this changed the Arabs and is the most evolutionary concept for all mankind.

\section{CONCLUSION}

PTST is a state-owned company operating in limestone mining. This requires PTST to perform TJSL (the consequence of business activities which is in direct contact with natural resources exploitation) and PKBL (the consequence as state-owned company). In its implementation, PTST had performed its obligation in implementing the two forms of CSR, but not maximally. The reason is that the CSR program implemented was not followed-up, thus it is not surprising that the program did not significantly affect the improvement of society's welfare and it was as if only to meet the responsibility mandated by the existing regulation. However, PTST claimed that they were aware that CSR was their necessity to actualize caliphate duties.

Besides obligation (mandated by regulation), on the other hand, it is also deemed as company's need. PTST is aware that their existence in the society should give positive impact on the society. PTST acknowledges that the best human is one who is useful to his surrounding people. This acknowledgement shows that PTST is aware that it is part of the society. PTST also acknowledges that human is God's representative on earth, but in the implementation PTST has not proven it to be correct.

The duality (as obligation and as necessity) in CSR implementation causes doubt in settling social and environmental issue at society level. PTST considers that the government should take a bigger part in settling the issues. Finally, PTST does not allocate its profit (max 4\%) in the current year for CSR budget 
although company's financial position is profit. PTST states that it does not violate the regulation since it has allocated a fund for CSR program which is from administrative cost and loan interest of partnership program.

Implementing CSR for regulatory obligation does not indicate business player's awareness to participate in improving society's welfare, eradicating poverty, and inequality, leading to moral dislocation. Not allocating corporate profit to social and environmental responsibility program shows that there is no income distribution by PTST to deal with the impacts of its corporate business acts and decisions. Meanwhile, Islam commands each Muslim to spend their property in the way of Allah, which is the excess of their needs.

Deliberative CSR does not only pay attention to worldly aspect, but presents worldly and heavenly relationship, like Islamic worldview. The result of elaboration of CSR concept with Islam as the liberation ideology is as follows: First, the concept of tazkia. Second, the concept of justice. Third, the balance of nature. Fourth, social welfare. Deliberative CSR liberates CSR from materialism's capitalistic worldview; that is implementing CSR as (regulatory) obligation, image, and obtaining certain award. Deliberative CSR makes entity perform CSR not limited to obligation, but beyond obligation; that is as human's need to actualize their duties as God's representative on earth as the consequence of devotion to Allah SWT. Business which is only oriented to profit causes unethical behavior by justifying and performing any way for profit. This has caused problem; social problem and environmental problem, thus the international society demands business's responsibility for current socio-economic condition. The existence of CSR as company's commitment to get involved in improving the quality of useful society and environmental life is the society's new hope.

\section{REFERENCES}

Al-Ghazali. (1996). Ihya' Ulumuddin. Terjemahan oleh Ismail Yakub. Semarang: CV. Faizan.

Beittinger-Lee, V. (2010). (Un)Civil Society and Political Change in Indonesia: a Contested Arena. London: Routledge.

Boubakary., \& Moskolai, D. D. (2016). The Influence of the Implementation of CSR on Business Strategy: An Empirical Approach Based on Cameroonian Enterprises. Arab Economic and Business Journal, 11, pp. 162-171.

Brammer, S., Williams, G., \& Zinkin, J. (2007). Religion and Attitudes to Corporate Social Responsibility in A Large Cross-Country Sample. Journal of Business Ethics, 71 (3), pp. 229-243.

Carroll, A.B., \& Shabana, K.M. (2010). The Business Case for Corporate Social Responsibility: A Review of Concepts, Research and Practice. International Journal of Management Reviews, 12, pp. 85-105.

Croker, N.C., \& Barnes, L.R. (2017). Epistemological Development of Corporate Social Responsibility: The Evolution Continues. Social Responsibility Journal, 13 (2).

Creswell, J.W. (2015). Penelitian Kualitatif dan Desain Riset, Memilih di antara Lima Pendekatan [Qualitative Research and Research Design: Selecting among Five Approaches]. Yogyakarta: Pustaka Pelajar.

Deegan, C. (2002). The Legitimising Effect of Social and Environmental Disclosures: A Theoretical Foundation. Accounting, Auditing, \& Accountability Journal, 15 (3), pp. 282-311.

DiMaggio, J.P., \& Powell, W.W. (1983). The Iron Cage Revisited: Institutional Isomorphism and Collective Rationality in Organizational Fields. American Sociological Review, 48, pp. 147-160.

Dusuki, A.W. (2008). What Does Islam Say About Corporate Social Responsibility (CSR)? Review of Islamic Economics, 12 (1), pp. 2-28.

Djamhuri, A. (2011). Ilmu Pengetahuan Sosial dan Berbagai Paradigma dalam Kajian Akuntansi [Social 
Sciences and Various Paradigms in Acconting Studies]. Jurnal Akuntansi Multiparadigma [Accounting Journal of Multiparadigms] Universitas Brawijaya, 2 (1).

Engineer, A.A. (1999). Islam dan Teologi Pembebasan [Islam and Liberation Theology]. Translated by Agung Prihantoro. Yogyakarta: Pustaka Pelajar.

Freeman, R., \& Reed, D. (1983). Stockholders and Stakeholders: A New Perspective on Corporate Governance. Californian Management Review, 25 (2), pp. 88-106.

Friedman, M. (1970). The Social Responsibility is to Increase its Profits. The New York Times Magazine.

Gallhofer, S., \& Haslam, Jim. (2004). Accounting and Liberation Theology. Accounting, Auditing \& Accountability Journal, 17 (3), pp. 382-407.

Gambling, T., and Karim, R.A.A. (1991). Islam and Social Accounting. Mansell Publishers, London.

Hassan, A. (2016). Islamic Ethical Responsibilities for Business and Sustainable Development. Humanomics Journal, Vol. 32 No. 1 pp. 80-94.

Irianto, G. (2006). Dilema Laba dan Kerangka Teori Political Economy of Accounting (PEA) [Profit Dillemma and Theoretical Framework of Political Economy of Accounting (PEA)]. TEMA, 7 (1), pp. 14-26.

Karaye, Y., Ibrahim., Ishak, Z., \& Che-Adam, N. (2014). The Mediating Effect of Stakeholder Influence Capacity on The Relationship Between Corporate Social Responsibility and Corporate Financial Performance. Social and Behavioral Sciences, 164, pp. 528-534.

Khurshid, M.A., Al-Aali, A., Soliman, A.A., \& Amin, S.M. (2016). Developing an Islamic Corporate Social Responsibility Model (ICSR). Competitiveness Review, 24 (4), pp. 258-274.

Lako, A. (2011). Dekonstruksi CSR dan Reformasi Paradigma Bisnis dan Akuntansi [CSR Deconstruction and Business\&Accounting Paradigm Reform]. Jakarta: Erlangga.

Lee, M.P. (2008). A Review of the Theories of Corporate Social Responsibility: Its Evolutionary Path and The Road Ahead. International Journal of Management Reviews, 10 (1), pp. 53-73.

Lee, E., Lee, H.J., Pae, J.H., \& Park, S.Y. (2013). The Important Role of Corporate Social Responsibility Capabilities in Improving Sustainable Competitive Advantage. Social Responsibility Journal, 12 (4).

Moleong, J.L. (2013). Metode Penelitian Kualitatif [Qualitative Research Method]. Bandung: Rosda

Mustofa, A. (2010). Perlukah Negara Islam [Is Islamic Country Necessary]. Surabaya: PADMA Press

Porter, M., \& Kramer, M. (2002). The Competitive Advantage of Corporate Philanthropy. Harvad Business Review.

Republik Indonesia [Republic of Indonesia]. (2007). Undang-Undang No. 40 Tahun 2007 Tentang Perseroan Terbatas [Law No. 40 Year 2007 on Limited Liability Company]. Jakarta: Sekretariat Negara [State Secretariate].

Undang-Undang No. 25 Tahun Penanaman Modal [Law No. 25 on Capital Investment]. Jakarta: Sekretariat Negara [State Secretariate].

Peraturan Menteri Negara Badan Usaha Milik Negara No. 09/MBU/07/2015 Tentang Program Kemitraan Badan Usaha Milik Negara dengan Usaha Kecil dan Program Bina Lingkungan [Regulation of Ministry of State-Owned Enterprises No. 09/MBU/07/2015 on Partnership Program of State-Owned Enterprises with Small Businesses and Environmental-Supervisory Program]. Jakarta: Sekretariat Negara [State Secretariate].

Peraturan Menteri Negara Badan Usaha Milik Negara No. 02/MBU/07/2017 Tentang Program Kemitraan Badan Usaha Milik Negara dengan Usaha Kecil dan Program Bina Lingkungan [Regulation of 
Ministry of State-Owned Enterprises No. 02/MBU/07/2017 on Partnership Program of State-Owned Enterprises with Small Businesses and Environmental-Supervisory Program]. Jakarta: Sekretariat Negara [State Secretariate].

Rakotomavo, M. (2012). Corporate Investment in Social Responsibility versus Dividends? Social Responsibility Journal, 8 (2), pp. 199-207.

Rice, G. (1999). Islamic Ethics and the Implications for Business. Journal of Business Ethics, 18 (4), pp. 345-58.

Sanders, Paul. (2012). Is CSR Cognizant of the Conflictuality of Globalisation? A Realist Critique. Critical perspectives on international business, 8 (2), pp. 157-177.

Stuebs, Marty, \& Sun, Li. (2012). Further Evidence on the Association Between Corporate Social Responsibility and Financial Performance. International Journal of Law and Management, 54 (6), pp. 472-484.

Sugiyono. (2009). Metode Penelitian Kuantitatif, Kualitatif, dan $R \& D$ [Quantitative, Qualitative, and R\&D Research Method]. Bandung: Alfabeta

Smirnova. (2012). Perceptions of Corporate Social Responsibility in Kazakhstan. Social Responsibility Journal, 8 (3), pp. 404-417.

Stohl, M., \& Stohl, C. (2010). Human Rights and Corporate Social Responsibility Parallel Processes and Global Opportunities for States, Corporations, and NGOs. Sustainability Accounting, Management and Policy Journal, 1 (1), pp. 51-65.

Triyuwono. (2016). Taqwa: Deconstructing Triple Bottom Line (TBL) to Awake Human's Divine Consciousness. Pertanika J. Soc. Sci. \& Hum. Vol. 24 pp. 89-104.

Waworuntu, S.R., Wantah, M.D., \& Rusmanto, T. (2014). CSR and Financial Performance Analysis: Evidence from Top ASEAN Listed Companies. Social and Behavioural Sciences, 164, pp. 493-500.

Wood, J.D. (2010). Measuring Corporate Social Performance: A Review. International Journal of Management Reviews, 12 (1) pp. 50-84. 